\title{
Nursing and hospitalized high-risk pregnant women: challenges for comprehensive care*
}

\author{
Enfermagem e gestantes de alto risco hospitalizadas: \\ desafios para integralidade do cuidado \\ Enfermería y gestantes de alto riesgo hospitalizadas: \\ desafíos para integralidad del cuidado
}

How to cite this article:

Souza BF, Bussadori JCC, Ayres JRCM, Fabbro MRC, Wernet M. Nursing and hospitalized high-risk pregnant women: challenges for comprehensive care. Rev Esc Enferm USP. 2020;54:e03557. DOI: https://doi.org/10.1590/S1980-220X2018036903557

\section{Bruna Felisberto de Souza ${ }^{1}$ \\ Jamile Claro de Castro Bussadori ${ }^{1}$ \\ José Ricardo de Carvalho Mesquita Ayres ${ }^{2}$}

Márcia Regina Cangiani Fabbro ${ }^{1}$

\section{Monika Wernet ${ }^{1}$}

* Extracted from the dissertation: "Enfermagem e gestantes de alto risco hospitalizadas: desafios para integralidade do cuidado", Programa de Pós-Graduação em Enfermagem, Universidade Federal de São Carlos, 2017.

${ }^{1}$ Universidade Federal de São Carlos, Programa de Pós-Graduação em Enfermagem, São Carlos, SP, Brazil.

${ }^{2}$ Universidade de São Paulo, Faculdade de Medicina, Departamento de Medicina Preventiva, São Paulo, SP, Brazil.

\begin{abstract}
Objective: To analyze the interactions between nursing and hospitalized high-risk pregnant women regarding the possibilities and limits of providing care guided by the principle of comprehensiveness. Method: A qualitative study based on the conceptual framework of comprehensiveness and developed from the precepts of thematic content analysis. Data were collected through open interviews and observation of the care scenario of twelve nursing professionals with hospitalized high-risk pregnant women. Results: Twelve (12) nursing professionals participated in the study. Nursing practices are portrayed from two thematic categories: "Embracement: emotional and informational support" and "Assessing and monitoring gestational risk". The findings revealed intentions to embrace women, providing informal and emotional support, but under weaknesses in intersubjective relationships. There is an emphasis on "technical success", not always sufficiently articulated with "practical success" in care actions, with harm to achieving comprehensiveness. Conclusion: The findings revealed that an emphasis on the biomedical management of obstetric risk and structural and organizational limitations of work end up hindering incorporating into daily care the concerns and knowledge necessary for constructing its comprehensiveness.
\end{abstract}

\section{DESCRIPTORS}

Obstetric Nursing; Integrality in Health; Humanization of Assistance; Pregnancy, HighRisks; Nursing, Team. 


\section{INTRODUCTION}

Comprehensiveness is a doctrinal principle of the Unified Health System (SUS - Sistema Único de Saúde) which proposes a dialogic basis between the technological, ethical and political dimensions of health actions. Although it is a polysemic concept, the search for comprehensiveness in the form of service organization is based on the need to overcome reductions and technicalities which compromise the effectiveness of healthcare. In other words, it calls for an expanded response to individual and collective health needs which does not reduce them to biological aspects ${ }^{(1-2)}$.

In the historical development process of modern medicine, the focus on scientific knowledge and managing disease in its morphofunctional manifestation devalued subjectivity, the existential sphere of the person and emphasized the domain of technical-instrumental knowledge ${ }^{(3)}$. It was no different with the issues of birth and labor. Its institutionalization and medicalization transformed the natural and inherent process of the female into a pathological event in need of control and with an exacerbated exercise of interventionist power of professionals, especially physicians ${ }^{(4)}$. Therefore, the current model of childbirth care reduces women to a mere object of the health team, without meeting their specific needs at a time of high vulnerability.

In pregnancies which develop under a high risk diagnosis, being understood as an obstetric situation that can result in unfavorable outcomes to the health of the mother and/or the fetus ${ }^{(5)}$, the subjective devaluation intensifies. Morphofunctional management of the situation is exacerbated by the technical and interventionist look, which on the one hand is justified by the obstetric risks involved in the situation, and on the other hand makes the commitment to the other dimensions involved in the care challenging for such a rich experience of practical implications and existential meanings such as pregnancy and childbirth, especially when there is hospitalization of women ${ }^{(6)}$.

In these situations, it is necessary (although more difficult) to maintain the perspective of comprehensiveness as a guiding principle of healthcare. It considers and values the subjectivity of meetings and listening, with a view to dialogue as a way to contextualize health actions in the unique context of people and collective population groups ${ }^{(7)}$. For this, the active presence of pregnant women and their protagonism is essential, despite all the difficulties involved in the situation, as well as respect and fostering their autonomy on the part of professionals ${ }^{(8)}$.

A national study on prenatal care and the itinerary of high-risk pregnant women in the pregnant woman's voice from the perspective of comprehensiveness revealed a lack of longitudinality and continuity of prenatal care, as well as fragility in interactions with a comprehensive and participatory approach, which contributed to a loss of women's right to act regarding their body ${ }^{(9)}$. Therefore, it is urgent to broaden reflections and evidence about the comprehensiveness of care for high-risk pregnant women, as well as the importance of women's roles in constructing healthcare in the pregnancy-puerperal cycle ${ }^{(10)}$. In this sense, the present study aims to analyze the interactions between nursing and hospitalized high-risk pregnant women regarding the possibilities and limits of care delivery guided by the principle of comprehensiveness.

\section{METHOD}

\section{STUDY DESIGN}

This is a field study with a qualitative focus seeking to explore the interactions of the nursing team in producing care for hospitalized high-risk pregnant women. The concept of Comprehensiveness as systematized by Ayres was taken as the base for the production and interpretation of his empirical material ${ }^{(11)}$.

Comprehensiveness is effectuated in the way services are organized in terms of management and care ${ }^{(1)}$. The way of operating care based on comprehensiveness, inseparable from the other doctrinal principles of SUS of universality and equity, leads professionals to the challenge of knowing "what" to do and "how" to do care actions for everyone, taking into account the needs of each one ${ }^{(11)}$.

In this sense, four organizing axes of comprehensive-oriented care actions are pointed out: (1) the axis of needs: this refers to a reading which does not limit the object of health work to the morphofunctional aspects of the disease or its risks, but incorporates these aspects into constructing care which is situated in the concrete context, and according to the practical interests of its recipients. The quality of listening and meeting the demands are put into the agenda; (2) the axis of purposes: this concerns the integration between health promotion, disease prevention, treatment of disease and suffering, and health recovery/social reintegration actions according to the uniqueness of each care situation; (3) the axis of articulations: this concerns the interactions between the different knowledge and professions in developing health actions. The guiding sense here is to work in an interdisciplinary and intersectoral manner according to the needs and purposes involved; (4) the axis of interactions: this concerns intersubjective interactions. The guidance here is the construction of effective dialogue between the involved subjects, without which the above axes cannot be effectuated ${ }^{(11)}$.

As it turns out, providing quality care in the complex situation of women who are pregnant in high risk conditions brings challenges implied in the four axes described above, which will be the basis of the research presented herein.

\section{Population}

A total of 12 nursing professionals participated in the study. Of these, six are obstetric nurses, four are nursing technicians and two are nursing assistants. Upon observation, a total of 13 high-risk hospitalizations were followed. The inclusion criteria selected were: nursing professionals who were not on vacation and pregnant women over 18 years old, hospitalized and diagnosed with an at-risk pregnancy, which is a criterion that was only adopted for the observation process. The participants' narratives transcribed 
herein were identified according to their initials: Nurses (N); nursing technicians (NT) and nursing assistants (NA), followed by the numerical sequences in which the interviews were transcribed.

\section{Data COllection}

The study was developed in a maternity hospital in the interior of São Paulo, which offers care to high-risk pregnant women with hospitalization needs. This maternity hospital is located in a philanthropic hospital and reserves seven beds for pregnant women. For the care of these women, the expected nursing staff for each shift (12-hour work regime) is one obstetric nurse and two or three nursing technicians/ assistants.

The production of empirical material took place between December/2016 and January/2017 from: (1) open interviews guided by the question: "Tell me what you seek to value in your care provided to hospitalized high-risk pregnant women?" And (2) observation of the care scenario which was carried out with attention to the axes of needs, purposes, articulations and interactions, recorded in field diaries. The interviews were conducted and transcribed by the first author of this article together with the data from observing the care scenario, and constituted the guiding instruments of the analysis. Observation of the service was performed in all four shifts following the strategy: all shifts were observed at the same period to approach the care routines over a period of three hours, totaling twelve observation hours, on consecutive days. Thus, day shifts were observed from 07:00 (shift start) to 10:00, and night shifts were observed from 19:00 (shift start) to 22:00.

\section{DATA ANALYSIS AND PROCESSING}

Bardin's Thematic Content Analysis ${ }^{(12)}$ was selected as a methodological framework, which is a method encompassing a set of analysis techniques that enable understanding communication products. It is developed from three steps. The first step is the pre-analysis, and aims at organizing the empirical material through repeated readings and cutting the text into comparable categorization units. The second step is exploration, in which the material is codified and the raw data of the text are transformed into content representation associated with the nuclei of meaning. In the last stage, this material is interpreted and exposed in order to recompose the phenomenon ${ }^{(12)}$. No qualitative software was used in this analysis.

\section{ETHICAL ASPECTS}

All participants signed the Informed Consent Form (ICF) and agreed to participate in the study voluntarily. There was a need for pregnant women to also sign the informed consent form after authorization for observation granted by them to the first author, considering the observation of the care field. The study development complied with the national and international standards of research ethics involving human beings and was approved by the Research Ethics Committee, under Opinion No. 2.239.519/2016, in accordance with Resolution 466/2012 of the National Health Council ${ }^{(13)}$.

\section{RESULTS}

The average age regarding the 12 nursing participants was 30.5 years, ranging from 23 years (minimum age) to 39 years (maximum age). The training time of professionals at their respective levels (obstetric nurses, nursing technicians and nursing assistants) was on average 4.41 years, with a maximum of eight (8) years and a minimum of one (1). Regarding length of service in the maternity ward, the average was approximately two (2) years and ten (10) months, ranging from two (2) to eight (8) years of practice. In the observation process, the causes for obstetric hospitalizations were: premature labor; twin pregnancy; hypertrophic heart disease; pre-eclampsia; hydatidiform mole; ectopic pregnancy; urinary tract infection; and pyelonephritis.

The understanding/interpretation of the nursing care practice studied herein was systematized from the following thematic categories: "Embracement: emotional and informational support" and "Assessing and monitoring gestational risk", which were discussed with the contributions from observing care scenarios.

\section{EMBRACEMENT: EMOTIONAL AND INFORMATIONAL SUPPORT}

The narratives revealed an active concern to promote comfort and meet the needs of women in nursing care offered to hospitalized high-risk pregnant women. However, only one of the nurses interviewed revealed her position on the protagonism of pregnant women when she reported the importance of respecting her wishes.

(...) the care to be together, to have a calm, peaceful environment, and to have care which is a peaceful and humanized care (N1).

Do everything the way they want, do the things they want as far as possible... respect their wishes (N2).

The nursing team perceives a psychological overload in pregnant women due to the at-risk situation. They point to feelings of fear, worry and apprehension in situations in which it is evident there is no knowledge or a lack of knowledge about the gestational condition, and highlight that being unaccompanied during hospitalization aggravates the emotional imbalance. In this sense, the action of providing emotional and informational embracement gains centrality. Sometimes they don't understand what's going on, so they'll be super [intonation in voice] worried about the fetus for sure. So, I always try to talk and solve their doubts because I know they always get, how can I can say, apprehensive about it ... and I always say that if she has any questions she can come talk with us (N4).

They are always thinking the worst, you know?! They think the worst with the other children who are at home, sometimes with the husband who is at home... others are shaken because there is no relative who comes here to visit and they feel lonely here, they feel abandoned (NA1). 
Faced with hospitalization, the team assumes the guiding action with commitment and priority. They make efforts to recognize this need, valuing complaints, doubts and using non-technical language, which can break barriers. In understanding that the family lives the experience of gestational risk and its repercussions on the woman, this expands the embracement. It signals the importance of involving, dialoguing with and approaching the family to know their needs. Never leave it in doubt, if she asks something and we don't know, try to at least have some notion to say something, you don't have to use any technical terms, but something that they understand, because to leave it in doubt, I think it's worse than not know what is happening. So, I check, I think the best thing is that you always try to respond (...) (NT4).

(...) you have to involve the family, bring the family at the visit time and talk to this family, explain to this family, and call the doctor to this family and often the brother, uncle come, and then another part of the family, and you have to have patience [intonation in voice] to be explaining every time the family needs it, and you have to understand this (...) (N3).

However, these actions are restricted due to the operational limitations perceived by the participants. The interviewees reveal a lack of time to guide due to the institutionally prospected tasks and the institutional/organizational limiting rules for this support.

A high-risk pregnant woman always has many doubts about her clinical status, her family members too, so I think the first thing is the orientation of her condition, which is sometimes a difficulty we have, as it is very busy [referring to the on duty] (N1).

(...) because some days the demand is very high, they want to ask questions, the family wants to talk (...) so I like to make these guidelines, but there are days that really do not let you (N5).

Since hospitalization is recognized as aggravating psychological overload, the nursing team intervenes to make the institutional rules more flexible, seeking to enable extended visits and/or companions for these women, although this has been observed in rare situations.

When it's a hospital stay, they [pregnant women] aren't entitled to a companion, so they end up being alone and I have to explain why, because they often ask if they need to be alone. Our space here does not collaborate so that all hospitalized pregnant women can be with someone (N4).

When I feel the need, when the patient is very sad, crying, we try to [pause] ... allow a companion (...) (N3).

Hospital rules regarding the presence of the family in the sector allow daily visits from $12 \mathrm{~h}$ to $20 \mathrm{~h}$, lasting one hour for each visitor and without the right to accompany the woman older than 18. It was observed that the team instructs family members to leave before the team's entry into the room, which compromises the axis of interactions, as the family is not an integral part of care in the care practice.

Moreover, in line with the narratives, observing the daily lives of the clinical inpatient unit demonstrated an effective process of informing women about the procedures and medications to be performed. Nursing uses more informal conversation as a communication strategy and seeks to guide and explain all procedures, which facilitates interaction.

General care ... I think it's very important that we always identify ourselves to the patient, very important we explain all the procedures that will be performed. I see the Cardiotocography [CTG] very regularly, for example, which we do millions a day and we do and do in that routine and sometimes the patient doesn't know why! You don't know what those little things do ... so I think we'll get there - look this little thing will be listening to the baby, this little thing will see the uterine dynamics, movement - and that already takes away their anxiety. So they already know what it's for, and after you take the exam, we have the ability to evaluate the exam, so we can tell the patient - it's okay, your baby is fine - it reassures the patient (...) (N3).

(...) I always seek through my shift change to clarify for them [women] what is pending examination, what is waiting, what has changed and why I am taking that medication (N6).

However, the information provided was strictly related to the pathophysiological and clinical aspects of obstetric management of the situation, which may compromise fulfillment of the needs axis, especially in this context of gestational risk, in which the quality of listening and embracing demands is so necessary.

\section{ASSESSING AND MONITORING GESTATIONAL RISK}

The interviews point out the valuation of actions of evaluating and monitoring vital signs articulated with gestational risk. This action permeates and directs care, and the nurse has a central role in this aspect. Actions of a technical-instrumental nature, directed by the high risk diagnosis which determined the hospitalization are highlighted.

In interactions with the women, they are concerned with identifying the risks and failures in treatment adherence. When identified, there is a tendency to blame women for therapeutic outcomes. In approaching pregnant women, they value the signs and symptoms which reflect the evolution of hospitalization, with an emphasis on vital signs, diet, vaginal bleeding and medication supply.

Sometimes she arrives after being transferred from some other hospital and then when she arrives the nurse's job is to do an evaluation, to listen to the fetal heart rate [FHR], to see how she arrived. Then the doctor also does an assessment and then the nurse clarifies the questions based on medical diagnosis and guidance, because sometimes some doctors may not clarify them [laughs]. So, the nurse clarifies the questions, then monitors the patient and is already taking care ... is doing this ... according to the prescription and depending on the diagnosis (N1).

I always try to be aware of the blood pressure which varies, right? It is varying all the time, but there are pregnant women who are a little stubborn, they are already hospitalized with high blood pressure and yet with high blood pressure they insist on wanting salt, wanting to put salt on top of food, then I advise them that... they need to help the baby and not just think about them because what is at risk is the baby's life (NA1). 
Control the bleeding right, the blood pressure, we always have to be controlling very high blood pressure, giving the prescribed medication, that's why (...) (NT2).

Nurses are involved in the follow-up of hospitalization and therapy, and have the role of informing the evolution of gestational risk among team members, especially physicians. It is noticed that physicians only request the shift change verbally, thereby eliminating any possibility of reading nursing notes.

Well, medical visits are performed daily and depending on the shift, the nurse always accompanies the visit, because it is through the visit that [the doctor] will refer to what they want you to do. For example, collecting exams, ordering cardiotocography, well ... other care. And then we see the patients together, so that we can even do the shift change with the doctor, right, as many times they do not get the information from the on-duty doctor who is in the maternity ward, they usually get it from a nurse and then we go along to be able to follow-up, see what their conduct is and what they will instruct tolfor the patient (N6).

In clarifying this follow-up, they report that they act as information links and that the moment of the medical visit is opportune to find out about the clinical case, prospecting future care for the woman. However, during the visits it was observed that the nurse's participation mainly consisted of listening and writing down conduct without any kind of manifestation and questioning to the doctor. When asked about her role in this follow-up, one of the nurses reported it being a time when "she doesn't open her mouth".

Therefore, we can infer that the joint axis in which the interactions between the different knowledge and professions in developing health actions should be visible was not contemplated, maintaining hierarchical and antidialogical relations between doctors and nurses, which compromises care based on comprehensiveness.

\section{DISCUSSION}

In the dynamics of the nursing team of this study, the nurse assumes the role of managing care. From the formal point of view, knowledge about at-risk pregnancy is expected from them, from the pathophysiology to the conduct of the hospitalization process, which is up to them to evaluate and decide in situations when they have autonomy to do so. In addition to this social role, they assume the articulation of information in space, when they become the information link for physicians.

At this scenario, they report an attitude of interest in establishing dialogue, embracing and listening, especially meaning the act of informing as a need for care in the context of high gestational risk, as they recognize the lack of preparation of women in terms of knowledge. Reflecting this, guidance gains centrality in the nursing work process. This lack of information in the context of high risk has been discussed in the literature ${ }^{(14-18)}$, focusing on prenatal care and the hospitalization process ${ }^{(9,14,19)}$, and was the subject of notes in this study.

Some studies ${ }^{(14,19)}$ have shown that health professionals limit themselves to the physiological aspects of pregnancy when developing guidelines, focusing on the discussion of Nursing Care Systematization, especially from the risk of pregnancy and with specific excerpts from the pregnancy diagnosis ${ }^{(14,19)}$, although they recognize the meanings of fear, guilt, anxiety and uncertainties attributed to the gestation process in this context ${ }^{(19)}$. These feelings were also acknowledged by the staff of this study and it was a valued aspect in the informing act.

However, although nursing refers to concerns about the negative meanings attributed to the hospitalization condition, in reading the intersubjective interactions the team only moves a little towards valuing intersubjectivity, either by the biomedical emphasis or by the institutionalization of professionals in exhaustive routines. This makes it difficult and sometimes nullifies the possibility of effective dialogues, compromising the axis of interactions.

The presence of a companion promotes emotional and physical support benefits ${ }^{(20)}$, influences female empowerment ${ }^{(21)}$, is considered a safety marker of the care quality provided to women ${ }^{(22)}$, and as a consequence reinforces the autonomy and protagonism of women in the care process, respecting their rights, and should therefore be strengthened in institutions. Eventually there is a breach of institutional protocols aimed at facilitating greater contact of pregnant women with their families, which may signal evidence of an appreciation of these, but still weakened because it is not institutionalized and is dependent on momentary attitudes of certain professionals. One can infer that this weak reorganization does not support the comprehensiveness of care principles, since intersubjective interactions built through effective dialogue between the involved subjects do not actually materialize.

Thus, basing care focused on health needs or centered on the subject ${ }^{(23)}$ is a widespread action within the care practice of professionals and can lead to interaction quality, aiming to provide the best care in facing health and life demands. However, a great challenge is, as mentioned, to base care beyond the instrumental objective and the fragmented actions imposed by care practice. It requires efforts by professionals in the pursuit of women's subjectivity, beyond the immediate clinical need, which incorporates comprehensiveness and articulates their actions in a more humane way ${ }^{(24)}$. This effort should include qualified listening beyond the technical knowledge, which values the integrations between health promotion actions, disease prevention, disease treatment and health recovery/social reintegration according to the uniqueness of each care situation, as previously described.

Technical management of obstetric risk should not lose contact with the meanings assumed by the pregnant woman regarding pregnancy, risk and obstetric management. In other words, the disconnection between technical success and practical success ${ }^{(11)}$ may be responsible for failure to adhere to care.

This has led to reflect on the real health needs of these women. Do they have space to be heard? Does the team articulate their actions to respond to health needs? What are the real health needs of this population? How are health professionals identifying needs? 
Despite the statements of the nursing team to highlight concern with humanized and comprehensive care, one observed that in practice there are structural limitations for its effective realization in the studied context. The exercise of comprehensiveness demands nursing care in which there is the possibility of listening and therapeutic meetings, with goals to reduce negative feelings, and to open space for information exchange and care planning in conjunction with other professionals, and especially with the women themselves ${ }^{(19)}$ and their families. This aspect was little evidenced in the present research, given the inexpressive articulation between knowledge, nullifying the possibility of exchanging interdisciplinary experiences with a view to comprehensive and subjective care, compromising the axis of the articulations.

In this sense, the hospital scenario, historically marked by gender inequality, hierarchy and power relations ${ }^{(25)}$, compromises interdisciplinary and intersectoral work, and does not meet the needs and purposes of those involved. It requires an additional effort to provide comprehensive care to pregnant women in order to protect and promote female leadership in the search for a new care model. Such care must respect the woman's physiology, body and desires, being able to expand the autonomy of obstetric nursing actions and their ability to overcome the reductionism and subordination of their role in relation to strictly medical knowledge and medical practices ${ }^{(6)}$.

Based on the results of this research, the importance of investments in healthcare model reforms is reiterated, especially in hospitals, since (as observed) there are structural and organizational aspects which hinder the construction of comprehensive care, from the technical division of labor, subordinated to medical knowledge and work, up to the construction of norms and routines which, as one have seen, restrict the intersubjective interaction and autonomy of users and professionals.

The study design performed herein does not enable generalizing the described reality, but identifies elements for comprehensive interpretative possibilities capable of illuminating phenomena of the same nature in other contexts, broadening or particularizing the scope of the categories developed herein, while revealing weaknesses in interactions which compromise the effective exercise of comprehensive care. Thus, the development of other studies depicting different care scenarios which address the hospitalization situation of high-risk pregnant women is suggested regarding: (1) family and companion experience of hospitalized high-risk pregnant women; (2) the meaning of comprehensiveness for maternity managers and on the part of multiprofessional teams that work there; (3) the presence and form of discussions about comprehensiveness in training processes which constitute professionalization, as well as in the curricula of the health professions; (4) the organization characteristics of health work and the place of nursing work in high-risk pregnancy care.

\section{CONCLUSION}

The nursing team participating in this study evidenced intentions of interactions based on listening, embracement and responses to the biopsychosocial demands of high-risk pregnant women. However, the effectiveness of these interactions was not observed in daily work, which constitutes an obstacle to constructing comprehensive care.

The interactions were fragile, without openings and spaces for intersubjective exchanges, predominating the institutional culture of the biomedical model. Medical professionals and their knowledge dominate work organization; a fact which directly influences the way nursing conducts interactions based on instrumental risk assessment and monitoring actions and on prompt medical care.

The strong understanding of nursing regarding the need to emotionally embrace and provide information to hospitalized risk pregnant women and their families is also emphasized; however, the "technical success" pole ends up detaching from the "practical success" pole in daily practice, which constitute effective health care, and in turn limits the reach of comprehensiveness.

\section{RESUMO}

Objetivo: Analisar as interações entre enfermagem e gestantes de alto risco hospitalizadas quanto às possibilidades e limites de realização de um cuidado orientado pelo princípio da integralidade. Método: Estudo qualitativo, fundamentado na base conceitual da integralidade e desenvolvido a partir dos preceitos da análise de conteúdo temática. A coleta dos dados se deu através de entrevistas abertas e observação da cena assistencial de doze profissionais de enfermagem junto a gestantes de alto risco hospitalizadas. Resultados: Participaram do estudo 12 profissionais de enfermagem. As práticas de enfermagem estão retratadas a partir de duas categorias temáticas: "Acolhimento: apoio emocional e informacional" e "Avaliação e monitoramento do risco gestacional". Os achados revelaram intenções de acolher a mulher, provendo suporte informal e emocional, contudo sob fragilidades nas relações intersubjetivas. Há uma ênfase no "êxito técnico", nem sempre suficientemente articulado ao "sucesso prático" nas ações de cuidado, com prejuízos para o alcance da integralidade. Conclusão: Os achados revelaram que a ênfase no manejo biomédico do risco obstétrico e limitações estruturais e organizacionais do trabalho acabam por dificultar a incorporação ao cotidiano do cuidado de preocupações e saberes necessários à construção de sua integralidade.

\section{DESCRITORES}

Enfermagem Obstétrica; Integralidade em Saúde; Humanização da Assistência; Gravidez de Alto Risco; Equipe de Enfermagem.

\section{RESUMEN}

Objetivo: Analizar las interacciones entre enfermería y gestantes de alto riesgo hospitalizadas en cuanto a las posibilidades y límites de realización de un cuidado orientado por el principio de la integralidad. Método: Estudio cualitativo, fundado en la base conceptual de la integralidad y desarrollado a partir de preceptos del análisis de contenido temático. La recolección de datos se dio mediante entrevistas abiertas y observación de la escena asistencial de doce profesionales de enfermería junto a gestantes de alto riesgo hospitalizadas. Resultados: Participaron en el estudio 12 profesionales de enfermería. La prácticas de enfermería están retratadas mediante dos categorías temáticas: "Acogida: apoyo emotivo e informativo" y "Evaluación y monitoreo del riesgo gestacional”. Los hallazgos revelaron 
intenciones de acoger a la mujer, brindando soporte informal y emotivo, sin embargo bajo fragilidades en las relaciones intersubjetivas. Existe una énfasis en el "éxito técnico", no siempre articulado lo bastante con el "éxito práctico" en las acciones de cuidado, con perjuicios para el alcance de la integralidad. Conclusión: Los hallazgos desvelaron que el énfasis en el manejo biomédico del riesgo obstétrico y limitaciones estructurales y organizativas del trabajo terminan por dificultar la incorporación al cotidiano del cuidado de preocupaciones y saberes necesarios a la construcción de su integralidad.

\section{DESCRIPTORES}

Enfermería Obstétrica; Integralidad en Salud; Humanización de la Atención; Embarazo de Alto Riesgo; Grupo de Enfermería.

\section{REFERENCES}

1. Kalichman AO, Ayres JRCM. Integralidade e tecnologias de atenção à saúde: uma narrativa sobre contribuições conceituais à construção do princípio da integralidade no SUS. Cad Saúde Pública [Internet]. 2016 [citado 2018 maio 07];32(8):e00183415. Disponível em: http:// www.scielo.br/scielo.php?pid=S0102-311X2016000803001\&script=sci_abstract\&tlng=pt

2. Pinheiro R, Mattos RA, organizadores. Os sentidos da integralidade na atenção e no cuidado à saúde. Rio de Janeiro: UERJ/ABRASCO; 2009.

3. Contatore OA, Malfitano APS, Barros NF. Care process in the health field: ontology, hermeneutics and teology. Interface (Botucatu) [Internet]. 2017 [cited 2018 July 23];21(62):553-63. Available from: http://www.scielo.br/scielo.php?script=sci_arttext\&pid=S1414$32832017000300553 \& \operatorname{lng}=$ en \&nrm=iso\&tlng=en

4. Pimentel TA, Oliveira-Filho EC. Fatores que influenciam na escolha da via de parto cirúrgica: uma revisão bibliográfica. Univ Ciênc Saúde [Internet]. 2016 [citado 2019 dez. 12]. Disponível em: https://www.publicacoesacademicas.uniceub.br/cienciasaude/article/ viewFile/4186/3279

5. Brasil. Ministério da Saúde; Secretaria de Atenção à Saúde, Departamento de Ações Programáticas Estratégicas. Manual técnico gestação de alto risco. Brasília: MS; 2012.

6. Melo CMM, Florentino TC, Mascarenhas NB, Macedo KS, Silva MC, Mascarenhas SN. Professional autonomy of the nurse: some reflections. Esc Anna Nery [Internet]. 2016 [cited 2018 May 07];20(4):e20160085. Available from: http://www.scielo.br/scielo.php?script=sci_ arttext\&pid=S1414-81452016000400601\&lng=en\&nrm=iso\&tlng=en

7. Ayres JRCM. Cuidado e reconstrução das práticas de saúde. Interface (Botucatu). [Internet]. 2004 [citado 2018 jul. 19];8(14):73-92. Disponível em: http://www.scielo.br/scielo.php?script=sci_arttext\&pid=S1414-32832004000100005\&lng=en\&nrm=iso\&tlng=pt

8. Assis MMA, Nascimento MAA, Pereira MJB, Cerqueira ERM. Comprehensive health care: dilemmas and challenges in nursing. Rev Bras Enferm [Internet]. 2015 [cited 2018 May 07]; 68(2):333-8. Available from: http://www.scielo.br/scielo.php?script=sci_arttext\&pid=S0034$71672015000200333 \& \operatorname{lng}=\mathrm{en}$

9. Cabrita BAC, Abrahão AL, Rosa AP, Rosa FSF. The search for care by high risk pregnant in relation to integrality in health. Ciênc Cuid Saúde [Internet]. 2015 [cited 2018 July 23];14(2):1139-48. Available from: http://periodicos.uem.br/ojs/index.php/CiencCuidSaude/article/ view/24250/pdf_347

10. Santos ALC, Santini AM, Subutzki LS, Berlato LP, Marchiori MRCT, Souza MHT. Stork network and the gestate leadership: a review of the literature narrative. Disciplinarum Scientia. [Internet]. 2016 [cited 2018 May 07];17(2):319-29. Available from: https://www.periodicos. unifra.br/index.php/disciplinarumS/article/view/2039/1885

11. Ayres JRCM. Organização das Ações de Atenção à Saúde: modelos e práticas. Rev Saúde Soc [Internet]. 2009 [citado 2018 jul. 19];18(supl.2). Disponível em: http://www.scielo.br/scielo.php?script=sci_arttext\&pid=S0104-12902009000600003\&lng=en\&nrm=iso $\& \mathrm{t} \operatorname{lng}=\mathrm{pt}$

12. Bardin L. Análise de conteúdo. Lisboa: Edições 70; 2011.

13. Brasil. Ministério da Saúde; Conselho Nacional de Saúde. Resolução n. 466, de 12 de dezembro de 2012. Dispõe sobre diretrizes e normas de pesquisas envolvendo seres humanos [Internet]. Brasília; 2012 [citado 2018 ago. 16]. Disponível em: http://bvsms.saude.gov.br/bvs/ saudelegis/cns/2013/res0466_12_12_2012.html

14. Oliveira DC, Mandu ENT. Women with high-risk pregnancy: experiences and perceptions of needs and care. Esc Anna Nery [Internet]. 2015 [cited 2018 July 19];19(1):93-101. Available from: http://www.scielo.br/scielo.php?script=sci_arttext\&pid=S1414-81452015000100093\&ln $\mathrm{g}=\mathrm{en} \& \mathrm{nrm}=\mathrm{iso} \& \operatorname{lng}=\mathrm{en}$

15. Silva DVR, Silveira MFA, Gomes-Sponholz FA. Experiences with severe maternal morbidity: a qualitative study on the perception of women. Rev Bras Enferm [Internet]. 2016 [cited 2018 May 07];69(4):618-24. Available from: http://www.scielo.br/scielo.php?script=sci_ arttext\&pid=S0034-71672016000400662\&lng=en\&nrm=iso\&tlng=en

16. Tunçalp O, Hindin MJ, Adu-Bonsaffoh K, Adanu R. Listening to women's voices: the quality of care of women experiencing severe maternal morbidity, in Accra, Ghana. PLoS One [Internet]. 2012 [cited 2018 May 07];7(4):e44536. Available from: https://www.ncbi.nlm.nih.gov/ pmc/articles/PMC3432129/

17. Piveta V, Bernady CCF, Sodré TM. Perception of pregnancy risk by a group of pregnant women hypertensive hospitalized. Ciênc Cuid Saúde [Internet]. 2016 [cited 2018 July 19];15(1):61-8. Available from: http://periodicos.uem.br/ojs/index.php/CiencCuidSaude/article/ view/28988/pdf_1

18. Richter MS, Parkes C, Chaw-Kant J. Listening to the voices of hospitalized high-risk antepartum patients. J Obstet Gynecol Neonatal Nurse. 2007;36(4):313-8.

19. Amorim TV, Souza IEO, Moura MAV, Queiroz ABA, Salimena AMO. Perspectivas do cuidado de enfermagem na gestação de alto risco: revisão integrativa. Enferm Glob [Internet]. 2017 [citado 2018 maio 07];(46):515-29. Disponível em: http://scielo.isciii.es/pdf/eg/v16n46/ pt_1695-6141-eg-16-46-00500.pdf

20. Souza SRRK, Gualda DMR. The experience of women and their coaches with childbirth in a public maternity hospital. Texto Contexto Enferm [Internet]. 2016 [cited 2018 July 19];25(1): e4080014. Available from: http://www.scielo.br/pdf/tce/v25n1/en_0104-0707tce-25-01-4080014.pdf 
21. Dulfe PAM, Lima DVM. Presence of a companion of the woman's choice in the process of parturition: repercussions on obstetric care. Cogitare Enf [Internet]. 2016 [cited 2018 July 19];21(4):1-8. Available from: https://revistas.ufpr.br/cogitare/article/view/37651/pdf_en

22. Diniz CSG, d'Orsi E, Domingues RM, Torres JA, Dias MA, Schneck CA et al. Implementation of the presence of companions during hospital admmission for childbirth: data from the Birth in Brazil national survey. Cad Saúde Pública [Internet]. 2014 [cited 2018 July 19 ];30 Supl 1:S140-S153. Available from: http://www.scielo.br/scielo.php?script=sci_arttext\&pid=S0102-311X2014001300020\&lng=en\&nrm=iso\&t Ing=en

23. Souto BGA, Pereira SMSF. História clínica centrada no sujeito: estratégia para um melhor cuidado em saúde. Arq Bras Ciênc Saúde [Internet]. 2011 [citado 2018 jul. 19];36(3):176-81. Disponível em: https://www.portalnepas.org.br/abcs/article/view/58/57

24. Petersen CB, Lima RAG, Boemer MR, Rocha SMM. Health needs and nursing care. Rev Bras Enferm [Internet] 2016 [cited 2018 May 07];69(6):1168-71. Available from: http://www.scielo.br/scielo.php?script=sci_arttext\&pid=S0034-71672016000601236\&lng=en\&nrm= iso\&tlng=en

25. Sarges RC, López LC. A assistência ao parto na perspectiva de enfermeiras obstétricas em uma maternidade pública: desmedicalização e micropolíticas na linguagem de gênero. Rev Antropol [Internet]. 2016 [citado 2018 maio 07];(48):133-48. Disponível em: https:// periodicos.ufrn.br/vivencia/article/view/11574/8152 